\title{
Beyond behaviorism, positivism, and neo-institutionalism in economics: a conversation with Deirdre Nansen McCloskey
}

\author{
Deirdre Nansen McCloskey ${ }^{1}$ and Paolo Silvestri ${ }^{2 *}$ \\ ${ }^{1}$ University of Illinois, Chicago, Illinois, USA and ${ }^{2}$ Department of Economics and Statistics, University of Turin, Torino, Italy \\ *Corresponding author. Email: paolo.silvestri@unito.it
}

(Received 11 April 2021; revised 17 April 2021; accepted 18 April 2021)

\begin{abstract}
Silvestri interviews McCloskey about her forthcoming book, 'Beyond Behaviorism, Positivism, and Neo-Institutionalism in Economics', critical of recent economics, especially of neo-institutionalism. Neo-institutionalism uses the ugly character 'Herr Max U' as its central idea: the elevation of Prudence to the only virtue. Institutions are mainly intermediate, not ultimate, causes in society. Ethics, rhetoric, identity, ideology, and ideas matter. McCloskey's turn to defending liberalism is in the background of her critique of behaviorism, positivism, and neo-institutionalism as anti-liberal, reducing the analysis of people to a model of childish slaves. Liberalism is the theory of non-slave adults. Of the big ideas of the past few centuries, only liberalism treats people with suitable dignity, and permits them to have a go, and make others rich. Neo-institutionalism shares the two sins of modern Samuelsonian economics: a devotion of mere existence proofs; and a deviation to arbitrary tests of statistical 'significance'. And in its tale of a rise of 'capitalism', it shares the errors of amateur economic history. The better word for the modern economic world of the Great Enrichment - fully 3,000\% increases in real income per person - is 'innovism'. Neo-institutionalism, as the method of historical economics, must be replaced by 'Humanomics'.
\end{abstract}

Key words: Capitalism; Humanomics; innovism; Max U; neo-institutionalism; North

Paolo: Beyond Behaviorism, Positivism, and Neo-Institutionalism in Economics (McCloskey, 2021b) is the sister book or, rather, the twin book of Bettering Humanomics: A New, and Old, Way of Doing Economic Science (McCloskey, 2021a). Can you tell us a little bit how this two books project came about?

Deirdre: It's a long story. I am not mainly an economic philosopher, but an economic historian, and half of my two-dozen or so books claim to be scientific studies in that line. This year, for example, I am writing a big book on English medieval open fields and early modern enclosures, applying the quantitative and qualitative economic science that I and a few others call 'humanomics'.

When I taught in Economics at the University of Chicago, 1968-1980, I became vividly aware of how different the forms of argument there were from those of most of my teachers back at Harvard and MIT. I struggled to put the two together, and so read more philosophy of science, and then also literary criticism. Then in the 1980s and early1990s at the University of Iowa, I wrote three books of literary and philosophical criticism about the literature of my beloved teachers and colleagues and friends in economics and history.

The first of the three books on methodology, in 1985 ( $2^{\text {nd }}$ ed. 1998), said that economists were poets but didn't know it, the second (1990) that they were novelists unaware, and the third (1994) that they were epistemological necrophiliacs, passionately loving positivism without realizing that it was dead. 
For example, my colleague at the University of Chicago, Gary Becker was a poet, doing economic theory with metaphors. 'You know, Al', he said to Arnold Harberger when still a graduate student, 'children are just like durable goods. So the institution of marriage between $\mathrm{F}$ and $\mathrm{M}$ is like a little child-producing company'. Such Beckerian metaphors launched a thousand poems about a character named Herr Max U, a German-Burmese fellow who maximizes his utility subject to constraints.

Douglass North, a friend and fellow economic historian, was a novelist, doing history with stories (which technically in the departments of literature and of brain science are called 'metonyms', at the other end of the human mind from metaphors). North would say, 'Once upon a time we were poor. Then we dumped rules of the game on ourselves. And now as a result we are rich'. Stories of dumping institutions on poor countries have become dogma at the World Bank, replacing the earlier dogma (which was dumping capital on poor countries; neither dogma has worked).

And Uskali Mäki, later a friend and fellow professor of philosophy at Erasmus University of Rotterdam, would say, 'Your literary talk, Deirdre, is scandalously un-Scientific. Only analytic philosophy is proper for discussing a Science'. Such Mäkian philosophizing gave comfort to the numerous economists who believe that Samuelson in 1947 and Friedman in 1953 and Koopmans in 1957 were the last words we would ever need on Scientific Method.

As it was, my fellow economists would shout indignantly, 'How dare you call me a poet, novelist, or epistemologist! I'm a Scientist. By the way, what's an "epistemologist"?' Interestingly, the complaint by humanists by contrast was that such characterizations of economic science were boringly obvious. 'What else are human scientists', they asked in amazement that economists do not realize it, 'but poets, novelists, and epistemologists dreaming of a mobile army of metaphors?!'

I continued to work in economic history, such as turning in the 2000s to writing a long trilogy defending and explaining innovism (a better name for the ill-named 'capitalism'). But I also continued to think about scientific rhetoric. Because of the earlier book on rhetoric, I would be asked to comment in reviews and conferences on what was going on in economics and economic history. Neo-institutionalism was one of the main things going on, especially in economic history. I accumulated thoughts about it, and now have brought them together. The other book you mentioned, already out (2021a, spring), proposes humanomics as the way economics should go, a broader but more truly rigorous science of the ordinary business of life. The other, which we're talking about here (out in 2021b, autumn), is less cheerful, because it explores the numerous scientific dead ends that a narrowing and fake-precise positivism, behaviorism, and now neo-institutionalism has led us into. It's 'critical' in the more usual sense of disapproving. I published the positive book before the negative because the wise rule of ancient rhetoric, and modern pleading in court, is to put the refutation of one's opponent's case after making one's own case. It is better for persuading the jury, because as Adam Smith noted early in The Theory of Moral Sentiments, criticisms of an opponent arouse sympathy with him. In the present case, it would be a sympathy entirely unwarranted on scientific grounds.

I warned you that it was a long story. A still longer version, if you like that sort of thing, appears as an essay this year: 'Apologia Pro Vita Sua: A History of My Economic Opinions' (2021c).

Paolo: Could we say that this book has begun to take a clearer and more precise form through your article, published in this Journal, 'Max U versus Humanomics. A critique of neo-institutionalism'? (McCloskey, 2015) (By the way, the future reader might be interested to know that in your book, 'Mr. Max U' is defined as 'a narcissistic sociopath intent on maximizing his utility subject only to the constraint of the rules of the game'.)

Deirdre: Yes, Herr Max is Donald Trump raised to a scientific hypothesis. It is a version of Prudence, only. He follows the rules of the game - unless he can get away with cheating. (Donald cheats at golf.) And, yes: I don't know if the book is 'clearer and more precise' than the article, but it is at least a fuller treatment, with more examples, and later thoughts.

Paolo: 'Max U versus Humanomics' generated a challenging discussion with criticisms from leading scholars such as Greif and Mokyr (2016), Langlois (2016), Lawson (2016), and Tabellini (2016), and your concluding remarks 'The humanities are scientific: a reply to the defenses of economic 
neo-institutionalism' (McCloskey, 2016a). Is there anything in particular that you would like to retract or reconsider about that debate?

Deirdre: Well, no. In the discussion you mention, my friends deeply in love with neo-institutionalism spoke passionately of humans as loveless and speechless maximizers. They were mistaken, and sadly continue to be. They claimed further that culture is in fact included in neo-institutionalism - which it is not, not on any serious definition of 'culture', such as those involving ethics, rhetoric, identity, ideology, and ideas. They said that neo-institutionalism has in fact advanced beyond Herr Max and his Samuelsonian economics. No, it hasn't. They think, for example, that institutions are mere budget lines along which Max maximizes. On the contrary, institutions are human dances of ethics, rhetoric, identity, ideology, and ideas, with a prudent budget line in attendance, too. Most neo-institutionalists insist on not listening to the humanities. They sneer ignorantly at the departments of literature, philosophy, history, in favor of what they imagine takes place in neuroscience, confusing the brain with the mind and material interests with human action. Humanomics, by contrast, keeps the scientifically relevant parts of mathematics and statistics (and for that matter the recording of material interests, too, as in the virtue of prudence), yet acknowledges culture in such non-Max U virtues as love, temperance, courage, faith, hope, and love. In the 18th century, the ethics, rhetoric, identity, ideology, and ideas changed massively in northwestern Europe, leading to liberalism and innovism and our liberties and riches. The culture this sense has to change before institutions change - if they are to stay changed. It has to be working for institutions to work. Institutions, in a word, are human action.

Isn't all this obvious from, say, the recent political history of the United States? The presidency in January of 2017 was an institution with all sorts of lovely neo-institutional features, all of which Donald Trump the golf cheater proceeded in the next four years to blow sky high. Fortunately, like Italy during the early 1990s against the Mafia, certain judges found in their ethical upbringings the courage of action and in their professional identities the love of law which trumped Trump, just as James Madison and John Marshall had hoped. Otherwise the United States could well have gone the way of Turkey and Hungary - which both had the institutions of parliaments and courts and law books like the United States, but not the ethics, rhetoric, identity, ideology, and ideas to make such institutions work against the inclinations of a fascist. And even in the United States, the institutions such as the Congress and especially the Republican Party rolled over to the fascists like puppies. It was a close thing.

Setting up institutions of judgeships with wigs and gowns, and constitutions with law books and parliaments, does not prevent tyranny, or else Russia would be the liberal paradise that its black-letter laws have promised since 1924. It's what is lacking in James Buchanan's otherwise profound writings on constitutional political economy. Jim didn't have a theory of how to raise up people with the sort of integrity that he himself so notably had, to act as responsible attendees at his hypothetical constitutional convention.

I could go on, and on, and on. And have. The neglect of serious, quantitative and qualitative study of ethics, rhetoric, identity, ideology, and ideas deeply worries me for the future of my beloved economics and economic history. Max $U$ is not to be abandoned in all contexts. He does useful scientific work in many interesting cases, covered interest arbitrage and portfolio diversification. I have written whole books showing so. But he needs radical supplementation to get the economic science more broadly right. Neo-institutionalism doesn't do it.

For example, the neo-institutionalists Daron Acemoglu and James Robinson report on an attempt to curb absenteeism among hospital nurses in India by introducing the institution of time clocks (Acemoglu and Robinson, 2012: 450). The economist in charge of the experiment was sure that the bare incentives of the 'right institutions' would work. They didn't. The nurses conspired with their bosses in the hospitals to continue not showing up for work. Acemoglu and Robinson draw the moral that 'the institutional structure that creates market failures' is what went wrong. No. The continuing absenteeism was not about institutions or incentives or market failures. New institutions with the right, supposedly non-failing incentives had been confidently applied by the economist out of the 
tool kit of World-Bank dogma, and went wrong. The wrongness was instead about a lack of an ethic of self-respecting professionalism among the nurses, of a sort that, say, Filipino nurses do have, which is why they are in demand worldwide.

After all, the idea that institutions are anything other than merely intermediate causes is naïve on its face. As Demosthenes said, 'And what is the strength of the laws? If one of you is wronged and cries aloud, will the laws run up and be at his side to assist him? No; they are only written texts and incapable of such action. Wherein then resides their power? In yourselves, if only you support them and make them all-powerful to help him who needs them' (Demosthenes, 1935: 149 ${ }^{1}$ ).

Paolo: Let's focus now on Beyond Behaviorism, Positivism, and Neo-Institutionalism in Economics in more detail, starting with its title. In a telling passage of the Preface you claim that the main argument of the book is that 'neo-institutionalism, in parallel with other anti-ethical, positivist, neobehaviorist, coercive, and illiberal movements over the past few decades in economics, doesn't fit the bill for an ethical and scientific economics suited to free adults'. You accuse these approaches of treating 'creative adults like a flock of little children', that is to say treating us with the mere logic of 'incentives', or, I'd add, as if we were donkeys to be treated with a stick and a carrot. Can we say that your great concern and care for human freedom is what justifies dealing with Behaviorism, Positivism, and Neo-Institutionalism all together?

Deirdre: Yes, it is a conclusion I slowly came to, reflected, for example, in my book in 2019, Why Liberalism Works. I suppose it's not surprising that in the age of Trump, Erdogan, Orbán, Bolsonaro, Putin, Maduro, Duarte, and Crown Prince Mohammed bin Salman, one turns to defending liberalism. Everyone should. All hands on deck!

Paolo: Could you try to explain your conception of human freedom in more detail?

Deirdre: 'Liberalism' is used in the United States to mean 'tentative social democracy', in Latin American to mean 'conservativism run by the army'. I use it in the classical, Smithian way. I want to retire the silly coinage of the 1950s, 'libertarianism', which authorized the social democrats to make off with the honorable old word. The left wing of the Democratic Party in the United States has fled from the L-word, in favor of 'progressivism'. Let them have it. Then we can take back the L-word, advocating for Smith's 'liberal plan of [political] equality, [economic] liberty, and [legal] justice' (Smith, 1776, IV.ix.3: 664).

Liberalism is simply an egalitarianism of permissions, the political theory born in the late 18th century that no one should be a slave to others. It's not an egalitarianism of results or opportunities, which is Rousseau's version, at the headwaters of European socialism. It's from the Scottish, not the French, Enlightenment. Liberalism made for innovism and then the Great Enrichment of a shocking 3,000\% increase, 1800 to the present, in the real income of the poorest among us. And enriching consequences aside, liberalism suits the telos of a dignified adult. A slave is a child in rights. In the late 19th century, a European traveler asked a free American man who his master was. He replied, 'He ain't been born yet'. In 1935, the African-American poet Langston Hughes, admittedly no 19th-century liberal, expressed the core of liberalism well: 'O, let America be America again - /The land that never has been yet - /And yet must be - the land where every man is free'.

During the pregnant period 1776-1848, the clerisy of Europe birthed three big political ideas. Liberalism was the idea, radical in 1776, that hierarchies such as master/slave, official/citizen, husband/wife, paterfamilias/adult child should be overturned. They were to be replaced by a society of liberated adults with equal permission to buy anywhere and to set up businesses any time and to enter any profession and to move anywhere they wanted, and lately (to the distress of progressives) to say anything they want and (to the distress of conservatives) to marry anyone they want.

Nationalism, by contrast, was the anti-liberal idea coming into fashion in the early 19th century that everyone speaking the same language should be slaves to the central Nation, as a child to a Father. Socialism likewise was an anti-liberal idea coalescing during the revolutions of 1848 that everyone should be slaves to the central Plan, as a child to a Mother. Anyway the center was to be the

${ }^{1} \mathrm{I}$ am indebted to Tom Palmer for the citation. 
master, as against the dispersed orders arising in language and art and custom and science. Of the three clerical ideas, only liberalism was a good one, so good that it made the modern world. The clerisy loved the other two, because its men and women of system would be running things from the center, the gosplan or the industrial policy. Conceived in the 19th century and tried out on a big scale in the 20th, the ideas for the Nation and the Plan nearly ruined us. If you like nationalism and socialism, I like to say, perhaps you will like Nationalsozialismus.

Paolo: Is your concern and care for human freedom also connected to the call for more and more regulations around the world?

Deirdre: Yes. The statists such as the columnist and economist Paul Krugman hate to be called 'socialists'. More and more regulation and state expenditure, Paul thinks, is perfectly innocent. Regulations and expenditure will repair the ubiquitous 'imperfections' he discerns in voluntary human actions and their spontaneous order. Like other economists in the century of so since they defined themselves as masters of policy, to repair your imperfection-filled life, Paul has not troubled to measure the importance of the imperfections in the economy as a whole. Let's have more of those sweet, costless regulations, he says, to add to the one million federal regulations in the United States. And let's spend more taxes, advised by wise economists, such as Paul Krugman.

But when you obey the prince or pay his taxes you are of course his slave. A little bit slavery is acceptable to a true liberal - we aren't anarchists, after all, though we view them with sisterly indulgence. Let's have a little army to prevent the terrifying Canadians from invading the United States; let's have a little Centers for Disease Control and Prevention to fend off the next and much worse plague; and few others. But slavery, being ordered about by someone else without your consent, is slavery. That you pay coerced taxes for a massive modern state at $43 \%$ of your income means to be sure that you are only a slave on Mondays, Tuesdays, and Wednesdays. Congratulations. But a slave you are. If you don't think so, try not paying your taxes, or not obeying the regulations. You will be jailed. If you try to escape, you will be shot. Said Frederick Douglas, 'You have seen how a man was made a slave'.

Madmen in authority, it has been said, who hear voices in the air are distilling their frenzy from some academic scribbler a few years back. The distilled products are the Kool-Aid imbibed by the Politburo, the Council of the European Union, the Federal Reserve Bank, the Chinese Communist Party, the US Treasury, the IMF, the World Bank, the federal and state and local governments, Joseph Stiglitz, Paul Krugman, Elizabeth Warren, Marianna Mazzucato. The distillation's recipe calls for more and more expenditures and policies and regulations devised by saintly and omnicompetent masters advised by economists and calculators to govern the pathetic little lives of the misled, stupid, irrational little children. That's you, dears. You should care if such a distillation will enslave and then kill you.

Paolo: By the way, do you think that COVID-19 regulations, restrictions, recommendations, and the likes treated us like 'little children'?

Deirdre: I am conflicted. We liberals, I have said, are not consistent anarchists. We recognize that quarantines early in a plague might be a desirable use of the state's monopoly of coercion. There was in the United States a century ago a woman cook, Mary Mallon, who came to be called Typhoid Mary. She had (like young people these days carrying covid), asymptomatic but permanently infectious typhoid, this before it could be cured with antibiotics (likewise, covid). She didn't believe she was contagious because she didn't feel sick (nor do the young people hugging their grannies). As a cook she would spread typhoid, without malice, to people who ate her food. After she had infected dozens of people, and kept running away to infect more, she was in 1915 locked up for the final time, until she died, in 1938. The gross violation of her liberty was necessary, in view of the medical tools available at the time.

Yet we liberals worry that the extension of state power to quarantine the entire population against covid, whether successful or disastrous, will inspire the madmen in authority to further acts of sweet or not so sweet national socialism. As I said, conflicted.

Paolo: Reading the twin books one after the other, I had the impression that an important junction between the two is well represented by your interpretation of Lachmann's thought with particular 
reference to: (1) humans' 'spontaneity' and 'creativity', (2) his reading of Weber, and (3) the way you use Lachmann's Weber against North in particular, and neo-institutionalism in general. Could you comment on this (possible) junction and explain how these three points work together?

Deirdre: Yes, Ludwig Lachmann (1906-1990) has been a very late inspiration to me - and shows how slowly I grasped Austrian economics. He was a German from Berlin, who spent his academic career in South Africa. Remarkably, he was both a late student of the Marxist Werner Sombart and an early student and assistant of the highly non-Marxist Friedrich Hayek. He influenced American Austrians considerably when he would come, at Israel Kirzner's invitation 1974-1987 to teach for some months each year at New York University. What intrigues me about Lachmann is that like his students such as Don Lavoie (1951-2001), he takes a humanistic approach, à la humanomics. As Virgil Storr, Lachmann's intellectual grandson by way of Lavoie, points out, 'Austrian economics has moved in a decidedly Lachmannian direction' (Storr, 2019: 63). I call it a humanomical direction. My book, true, criticizes Austrian economics even of the Lachmannian sort for not being sufficiently quantitative. It's not only the socialists who fail in their scientific duty of answering How Big. But the other, 'twin' book celebrates the 'Lachmann direction' as a version of humanomics.

Paolo: In the central chapters of the book (Part II, Chps. 6, 7, 8, 9, 10), you dwell on the main deadly sins of neo-institutionalism, which make it, in short, 'not a scientific success'. Let's focus mainly on the first two (of course, you can add more sins to the black list, if you wish). The first is deficiency in measurement and/or an absence of quantification, right?

Deirdre: Yes, and they are surprising, in view of the quantitative pretensions of Samuelsonian economics, set forth in Tjalling Koopmans' book of 1957 - which we 1960s grad students read eagerly and believed. I've long noted that economists believe they are doing quantitative work when they find by a blackboard theorem that an equilibrium 'exists' and find by $t$ testing or $R^{2}$ that an effect is 'statistically significant'. What scientists actually do in physics, biology, geology, astronomy, or engineering is entertain a thought such as $F=m a$, evolution by natural selection, plate tectonics, gravitational clustering, or parallelograms of force, and then calculate by simulation the possible outcomes in view of parameters they observe more or less approximately in nature. Even historians, usually thought of as non-quantitative, would not be satisfied, as economists pridefully are, with a 'proof that causes of the US Civil War 'exist', or that a proffered cause is 'non-zero' in magnitude according to a convention of two standard deviations from the null. Like the physical scientists, the historians seek oomph.

Economists have been misled by the two techniques: existence learned from mathematicians (not engineers) and 'significance' from statisticians following R. A. Fisher (not Bayes). Both of the erroneous techniques ask whether/not, on/off, yes/no, exist/not. Neither technique has anything to do with a descriptive science. The actual job of a descriptive science is to ask and answer How Big by the standards of the ongoing conversation of the science, or of the policy to be implemented with it. The loss function has to be rhetorically substantive, not missing.

Like other Samuelsonian economists, the neo-institutionalists commit both errors. They offer 'analytic narratives' with no testing as to magnitude or as to comparative oomph, and they also test, test, test with meaningless 'significance'. Young economists have turned to big data. Good - or at least better than no data. But unhappily the only tool they have is tests of significance. Because their energies in graduate programs are spent on learning unscientific but mathematically amusing theorems, whether theoretical or statistical, they don't actually learn economic theory, understood as such propositions as that 'entry can drive rents to zero' or 'differentials tend to be arbitraged'. So in desperation, they recur to naïve Baconianism, assuming that numbers contain their own meaning without human judgment. Gosset asks Fisher, 'What sort of day is it in Lond?' Fisher replies, 'Six with standard deviation 0.76'. Gosset: 'But what does that mean? On what human scale with what human loss function?' Fisher: 'It means what I said, you dope, six. Six is six! What, don't you believe in numbers?!'

It's hard to get this elementary point across to people 'well trained' in economics. If well trained, they have had courses in the ill-named real analysis that make them think that existence theorems are scientific. No physicist would make such a strange mistake. Richard Feynman has an amusing story about his grad-school encounters with mathematicians that make the point. And if well trained in 
econometrics they go on and on ignoring the bankruptcy of Fisherian tests lacking a substantive loss function and applied to non-samples, yet under the supposition that sampling error is the only important one. In this, they ignore Edgeworth, Gosset, Egon Pearson, Jeffreys, Borel, Neyman, Wald, Wolfowitz, Yule, Deming, Yates, Savage, de Finetti, Good, Lindley, Feynman, Lehmann, DeGroot, Chernoff, Raiffa, Arrow, Blackwell, Friedman, Mosteller, Kruskal, Mandelbrot, Wallis, Roberts, Granger, Press, Berger, Zellner, and that excellent book by Ziliak and McCloskey.

Paolo: The second deadly sin is a wrong conception of 'culture' or, rather, a 'mistaken history', which cannot 'repair' the first sin.

Deirdre: I object to the facile replies one gets from neo-institutionalists to such complaints. It shows that most of them are not really thinking self-critically about what they are doing - about their rhetoric and their epistemology. They wave at the word 'culture' from afar and then claim that they've taken care of it. They do not read the novels, consider the philosophy, acknowledge the theology, examine the anthropology and sociology. Instead they offer an existence-theorem analytic narrative on superficially examined history and a significance-test regression coefficient on proxy variables of big data, and then walk away well satisfied. They say, as Douglass North did in his bizarre book of 2005, that they take ideas seriously, and then turn to brain science (of which the Good Douglass knew nothing at all). Brains matter, but they are matter, not the mind.

Paolo: Some scholars favor cultural explanations of economic development. Is your emphasis on the role of ideas a cultural explanation?

Deirdre: Of course it is. If the neo-institutionalists would take seriously the force of ethics, rhetoric, identify ideology, and ideas, no reasonable social scientist could object. Of course the institution of, say, the US Federal government 'mattered' to the causes of the Civil War. But equally 'of course' did the ethics of coercion, the rhetoric of Biblical citation, the identity of Southern-ness, the ideology of racism, the idea of abolitionism, without which all the institutions would not have mattered.

Paolo: You stress the importance of ideas. Where do ideas come from? Does culture play a crucial role in your account?

Deirdre: Ideas come from the genetic inheritance of Homo sapiens, from human upbringing, from plays, movies, comic books, fairy tales, rock music, advertising, political speeches, sacred texts, sermons, gossip, friends, philosophy, ritual, sports, marriage, and from the creative fruits of people liberated by liberalism 1776 to the present to have a go. You can see that ignoring the mind, as the neo-institutionalists and for that matter most economists since Ricardo insists on doing (though not our Blessed Founder, Adam), might be a fault in une science humaine. Admittedly, the tactic of self-imposed positivist ignorance has been a commonplace, if usually unconsciously adopted. Some of my own early writings on British entrepreneurship, for example, adopted the tactic. ${ }^{2}$ So, too with rather more consequence, do the sciences of humanity that identify the mind with the brain. Brain science of this sort is as though close study of the physiology of Sandy Koufax's arm would give a sufficient account of his baseball pitching in 1966. It's the new phrenology.

Consider what can be learned from the actual humanities and the actual brain sciences. Raymond Tallis, himself a distinguished neuroscientist, reviewed favorably Who's in Charge?: Free Will and the Science of the Brain by Michael S. Gazzaniga, whom he describes as 'a towering figure in contemporary neurobiology'. Tallis (2011) writes, sprinkling in phrases from Gazzaniga, 'Crucially, the true locus of this activity is not in the isolated brain' but 'in the group interactions of many brains', which is why 'analyzing single brains in isolation cannot illuminate the capacity of responsibility' [consider the contrast with the procedures in behavioral economics and some experimental economics]. This, the community of minds, is where our human consciousness is to be found, woven out of the innumerable interactions that our brains make possible. It is what Smith said in The Theory of Moral Sentiments in 1759: or what John Donne said in Devotions Upon Emergent Occasions xvii in 1624. Tallis continues: 'Responsibility (or lack of it), Gazzaniga says, "is not located in the brain." It is "an interaction between people, a social contract" - an emergent phenomenon, irreducible to brain activity.' Bart

${ }^{2}$ For which see some of the earlier articles in McCloskey (2020a). 
Wilson (2010), he of humanomics, made the same point about the sense of justice, and the one-by-one-person experiments by economists that miss the point. To deploy the old humanistic joke, the language speaks us as much as we speak the language.

Paolo: There is another issue that, in my opinion, returns frequently in your book, and explicitly in the chapters dedicated to neo-institutionalism. You conceptualize it in terms of the (always) problematic relationship between law and ethics. I too have always found the conception of law of neo-institutionalism quite poor, especially from the anthropological, ethical, and legal-philosophical point of view, that is, of human freedom and dignity. It is a bit as if Antigone had never existed for the neo-institutionalists. Would you agree with me if I said that the great absentee in the neo-institutionalist discourse is the great question of the relationship between the letter and the spirit of the law (to quote St. Paul)?

Deirdre: Yes. Lachmann was good on this, for example, but so was Albert Hirschman (1970) emphasizing that there is voice an exit as much as loyalty, or Kenneth Boulding $(1956,1973)$ speaking of the Image and his Quaker questioning of war, or nowadays Arjo Klamer $(2007,2017)$ about the struggles in values to do the right thing. Do we obey the laws? Should we? What to do, asked Antigone, if they conflict with each other? How to know? To your considerations of 'anthropological, ethical, and legal-philosophical' matters, I would add 'political' and 'personal'. Henry David Thoreau showed in his life a resistance to the ordinary and to the undignified obeying of what comes out of Max U, and inspired Gandhi and Martin Luther King. Doing the right thing is not a matter of snappy maximizing under constraints, no more than 'happiness' is to be understood by measurement on the three-point scale.

The neo-institutionalists claim they have this covered, when they talk of 'informal' institutions beyond blackletter law. But if law and ethics are merged into Max U, what has been achieved? It is the Neo-institutionalist Tautology. Society and psychology, they say, cause ... sociality and psychology. Well, yes. It is similar to the move of absorbing everything into Utility. Herb Gintis once asked me, on listening to me talk about the seven elemental virtues, why I didn't just put them into a utility function, U(P, T, C, J, F, H, L). His later work in 2011 with Sam Bowles suggested why not: people have identities.

Paolo: I wonder, and I ask you, if your critique of neo-institutionalist economists saves at least some old institutionalists. For example, none of them conceived legal and moral rules as carrot and stick, even if, it should be admitted, there was no in-depth reflection on human freedom on their part.

Deirdre: That's right, though I suppose it was as much a fault as a virtue, driving Gustav Schmoller and later John R. Commons to suppose that Max U and entry and opportunity cost did not matter at all. But before I make such a charge, I need to read more of Schmoller and Commons.

Paolo: Among the scholars usually labelled as 'neo-institutionalists' you save at least the Nobel laureate in economics Elinor Ostrom. As you write, she is 'one of a thin stream of practitioners of humanomics before the letter'. What's the difference between her and the other neo-institutionalists?

Deirdre: She accepted, indeed celebrated, that humans converse. The experimental economists Vernon Smith (Nobel 2002) and Bart Wilson and colleagues do experiments on Chapman University undergraduates in groups, not as individuals (Smith and Wilson, 2019). They are doing social science, not re-doing individual psychology less competently than the psychologists, which is something that experimental and observational behavior economics can rightly be accused of. Bart Wilson coined the word 'humanomics' and teaches with Jan Osborn, a colleague in the Department of English, a course in economics using Goethe's Faust and Zola's The Ladies' Paradise. (Yes, you heard that right. Steve Ziliak uses The Grapes of Wrath and I use Buddenbrooks and Citizen Caine to the same end of showing the kids that economics is about life.) But to the present point, Wilson and Smith listen to the side-talk of the their experimental subjects, and puzzle about it scientifically. That's the scientific spirit. Instead of banishing language, as economists such as George Stigler demanded we do, they listen and learn. Ostrom was the same. She listened (as, by the way, most women do, and many men do not). The Los Angeles aquifer was literally a common pool, and in the style of Max U considerations of the prisoner's dilemma, it was being drained. Ostrom (1990) noted that people talked their way out of the dilemma, and studied their solution in empirical detail. 
Paolo: In a recent public debate with Geoffrey Hodgson, organized by WINIR, ${ }^{3}$ as well as in the following 'amiable notes', you jotted down immediately after the conversation (McCloskey, 2020b), a substantial agreement emerged between the two of you. You wholly agree with his claim against Max U: 'pointing to the incentives and sanctions associated with rules is insufficient because it would not explain how individuals evaluate the sanctions or incentives involved. We also have to explain why they might, or might not, take incentives or sanctions seriously' (Hodgson, 2006: 12). This, you comment, 'is utterly destructive of the approach of North/Weingast/Grief/Acemoglu'.

Nonetheless, a methodological disagreement emerged, namely the problem of causation in historical explanations, and, in particular, in your explanation of the Great Enrichment, where 'institutions' and 'capital' are considered as 'intermediate': they 'are not causal in the way human ideas are indeed causal' (McCloskey, 2020b). According to Hodgson (2020), you seem inclined to consider the 'individual human agents [as] the only causes' of this type of explanations. Though it is true that 'neither institutions nor capital are causes [...] The key issue is whether they are part of the explanation. The Black Death is part of the explanation of the decline of serfdom in England. Institutions are part of the explanation of the Great Enrichment'.

Do you think that the distinction between sufficient and necessary conditions that you introduce in the first chapter of the book could resolve this methodological disagreement?

Deirdre: I'm not so sure I want to criticize Geoff. I think he is tending toward humanomics, so I don't want to discourage the tendency! Everybody knows that 'cause' is tricky. Our experience with courts of law should alert us to some of the problems. One big problem, seen now in the trial of the policeman involved in the death of George Floyd, is that for any event, there are literally an infinite number of necessary conditions. That is, if an infinitude conditions were not as they were, the event would not have happened: the union of not- $\mathrm{C}_{\mathrm{i}} \rightarrow$ not-E. That is, $\mathrm{E} \rightarrow \mathrm{C}_{1}$ and $\mathrm{C}_{2}$ and $\mathrm{C}_{3}$ and $\mathrm{C}_{4} \ldots$ and $\mathrm{C}_{\mathrm{i}}$ without end. The barn burned. Young Harry was smoking his first cigarette in the hay loft. But had the hay not been there, had the barn not been there, had the farm not been there, had the county not been there, had Harry not been there, had oxygen not been there, had the atomic weight of oxygen not been what it is, had Harry been instructed in smoking, had the universe not existed ... the barn would not have burned. No trick solves the problem. We decide what we regard as sufficient (Bohr: 'what we can say'), such as kneeling on George Floyd's neck for 9 minutes and 29 seconds. What we mean by 'sufficient' conditions is that $C_{s} \rightarrow E$. Notice that it's not the same implication as $E \rightarrow C_{1}$. But we always have to suppose in the background an infinite number of the necessary conditions, admittedly more and more remote.

In the present case, people say 'Obviously, rule of law caused the Great Enrichment. Look what would have happened without it'. That is the structure of North's books and Acemoglu and Robinsons's and the like. Look around for a necessary condition that one likes and then elevate it to sufficient. But the trouble is that the necessary conditions the neo-institutionalists elevate in explaining the Great Enrichment are commonplace. For example, the legalist neo-institutionalists always have English common law in mind, because they've heard that England had common law and it was where the Great Enrichment started. They do not realize that common laws were, well, common, all over, say, Europe; that Chinese law was very good, and so elsewhere; that the basic framework of English common law was set 'before the time of Edward I', that is, in 1272; and that law didn't change much in England until the 1830s; not, for example, in the Glorious Revolution of 1689, and many other points that they miss, showing that they haven't actually studied the legal history, such as Pollock and Maitland, The History of English Law Before the Time of Edward I. (1895).

I say that liberalism, which was in fact entirely new and unique to the Anglosphere in the late 18th century (though beginning to be imported a century before from Nederland), was sufficient - considering that a mass of necessary causes were already sitting there in England, though decidedly not unique to England: canals, banking, science, absence of an active civil war, existence of the universe, etc.

\footnotetext{
${ }^{3}$ See https://winir.org/?page=online\&side=winir_debates\&sub=great_enrichment.
} 
As to Geoff's remark that I want to confine 'causes' to the mental states of human individuals, yes. I recommend that everyone in this business read and consider the book by the philosopher, historian, and archaeologist R. G. Collingwood, The Idea of History (1946). Collingwood writes: 'The historian ... . is investigating not mere events (where by a mere event I mean one which has only an outside and no inside) but actions, and an action is the unity of the outside and the inside of an event' (Collingwood, 1946 (1993): 213). He uses 'action' as the Austrian economists do, 'mere events' being his term for merely physical events. Caesar crossing the Rubicon is his example. The physical action of crossing it was an 'event' in a behavioral sense. But its purposeful violation of Roman law was its 'inside' meaning - in Collingwood's sense, an action rather than an outwardly observed reaction to stimulus. Max $\mathrm{U}$ is external in this way, and would not know why Caesar did it - or at best (not a silly thing to do but incomplete) would reduce it to the cost/benefit calculation in view of the constraints he faced, which is a reaction, not the human action of a liberated will. Collingwood continues: 'When an historian asks "Why did Brutus stab Caesar?" he means "What did Brutus think, which made him decide to stab Caesar?" The cause of the event, for him, means the thought in the mind of the person by whose agency the event came about: and this is not something other than the event, it is the inside of the event itself (Collingwood, 1946 (1993): 214-215). Max U transforms the inside of the event, turning it so to speak inside out the better to reduce thought to 'observable', 'behavioral' reactions to 'objective' 'constraints' (my scare quotes here identify the philosophically naïve dogmas in Samuelsonian economics).

Paolo: In Conceptualizing Capitalism, Hodgson (2015: 37, 101-102) has claimed that your definition of 'capitalism' is too broad and your notion of 'property' is very loose. From Hodgson: 'McCloskey ruled out the possibility that the rise of capitalist institutions can have any explanatory role post-1700 because, for her, capitalism was defined in terms of "markets" (by which she meant any kind of trade) and the "market economy has existed since the caves" (McCloskey, 2010: 16). For her: "Market participants are capitalists" (p. 260). From this it seems that markets are sufficient to imply capitalism (this widespread view is criticized in [Hodgson's] later chapters). McCloskey was not alone in posing a very broad definition of capitalism.' I think this is the right 'place' and time to give him an answer.

Deirdre: The definition from the presence of markets was directed at the very many people who believe that markets are recent - for example, Karl Polanyi. Geoff knows better than Polanyi, but that does not make his definition of the silly word 'capitalism' more persuasive. I want us to stop using the word 'capitalism', a scientific error compressed into a word, like phlogiston or ether or witchcraft. It leads all manner of people, including economists, to regard capital accumulation as causal. Capital accumulation is in Collingwood's terms a mere event. The cause, as the Austrian well understand, is the creative human action of knowing that such-and-such a house might be good to build just here, or such-and-such a course in accounting might be wise to take, though the future be ever veiled (note the 'might'). In economics, a striking example of the mistake of taking $\Delta K$ as causal would be the so-called growth theory. But outside economics, the word has had a similarly baleful effect. The eminent sociologist and man of the left Immanuel Wallerstein wrote in 1983 (1995) that 'the word capitalism is derived from capital. It would be legitimate therefore to presume that capital is a key element in capitalism' (Wallerstein, 1983 (1995): 13). ${ }^{4}$ No, it would not. What we say about the world does not by virtue of saying become true, small-t. That we insist on ruminating on something called 'capital' does not imply that its accumulation was in fact unique to modernity, or indeed (here the Austrians join with the Cambridge, England Marxists) a meaningful concept in aggregate. Capital accumulation is something humans have always done. There was nothing special about how it was done in the 18th or 19th centuries, or in England. The high capital-output ratios of railroads led people to over-focus on $\Delta K$ and the savings rate and intermediation.

What was actually new and bizarre was the explosion of ideas, what Mat Ridley calls ideas having sex (Matt was trained as biologist, so such images occur naturally to him). So I suggest that we use

\footnotetext{
${ }^{4}$ So, since the first part of the word 'astrology' is derived from the Latin for 'star', it would be legitimate to presume that stars are a key element in human fate.
} 
'innovism' as the name for what is actually unique about the modern world. Not Geoff s 'capitalism'. It directs our attention to the actual, sufficient causes, which were the liberties of British people that made them bold to have a go. And go they did.

Paolo: To conclude, let's go beyond behaviorism, positivism, and neo-institutionalism. What is the way forward? What should scholars interested in institutional economics do?

Deirdre: They should try to get into the minds of people with some other tools that Max U models or the worst of brain science. At the crux you will find that neo-institutionalists concede the point. North, John Wallis, and Barry Weingast want to, in their book of 2009, be seen as tough-guy materialists. But when they seek explanations of the 'transition proper' to 'open access societies' (they do not for some reason want to use what everyone else calls it, 'liberalism'), they fall naturally into speaking of a rhetorical change. Good. Two crucial pages of their book speak of 'the transformation in thinking', 'a new understanding', 'the language of rights', and 'the commitment to open access'. (North, Wallis, and Weingast, 2009: 192-193). Though they appear to believe that they have a material explanation of 'open access to political and economic organizations', in fact their explanation for why Britain, France, and the United States tipped into open access is ideational (ibidem: 194). Ideas change, they are saying, as I am, through sweet talkas much as through material interests.

The same tough-guy preference for materialist events rather than causes is evident in Acemoglu and Robinson's latest book (2019). The neo-institutionalists want human action to be reducible to material incentives stripped of ideas or ideology. 'We emphasize', write Acemoglu and Robinson with a certain pride of Method, 'that the impact of various structural factors, such as economic conditions, demographic shocks, and war, on the development of the state and the economy depend on the prevailing balance between state and society' (Ibidem: 30). And again on p. 31: 'identify the structural factors making this type of zero-sum competition [are] more likely.... We emphasize several important structural factors.' When they turn to causes, material 'structure' and game theory rule. Not ideas. They see humans as rats in a structural maze, or a narrow corridor. Students even of animal behavior are slowly extracting themselves from the Cartesian/behaviorist dogma that an animal is a machine. They have discovered that animals sometimes act without incentives, which is the distinctive character of the 'human action' emphasized in Austrian economics.

Paolo: I would like to thank you from my heart, Deirdre, for your availability and the time you dedicated to this interview.

Deirdre: Il piacere è mio. Francis Bacon (whom I do not in fact admire, except for his Essays) said that 'Reading maketh a full man [and woman, dear], conference a ready man, and writing an exact man' (Essays, 'Of Studies', 1597 and 1525). Such conference as we have had makes my thinking fuller and more exact. Grazie mille.

Acknowledgements. I would like to sincerely thank Geoffrey Hodgson for granting the opportunity to publish this interview.

\section{References}

Acemoglu, D. and J. A. Robinson (2012), Why Nations Fail: The Origins of Power, Prosperity, and Poverty, New York: Crown Business.

Acemoglu, D. and J. A. Robinson (2019), The Narrow Corridor: States, Societies, and the Fate of Liberty, New York: Penguin. Boulding, K. E. (1956), The Image: Knowledge in Life and Society, Ann Arbor: University of Michigan Press.

Boulding, K. E. (1973), The Economy of Love and Fear, Belmont, CA: Wadsworth.

Bowles, S. and H. Gintis (2011), A Cooperative Species: Human Sociality and Its Evolution, Princeton: Princeton University Press. Collingwood, R. G. (1946 (1993)), 'Epilegomena: 3: Historical Evidence', in with an introduction by J. Van der Dussen (ed.), The Idea of History. Revised edition, Oxford: Oxford University Press, pp. 249-282.

Demosthenes. (1935), 'Against Meidias', in J. H. Vince (trans. by), Orations XXI-XXVI, Cambridge: Harvard University Press.

Feynman, R. (1997), Surely You're Joking, Mr. Feynman! (Adventures of a Curious Character), New York: W.W. Norton. Greif, A. and J. Mokyr (2016), 'Institutions and Economic History: A Critique of Professor McCloskey', Journal of Institutional Economics, 12(1): 29-41. 
Hirschman, A. O. (1970), Exit, Voice and Loyalty: Responses to Decline in Firms, Organizations, and States, Cambridge, Mass.: Harvard University Press.

Hodgson, G. M. (2006), 'What Are Institutions?', Journal of Economic Issues, 40(1): 1-25.

Hodgson, G. M. (2015), Conceptualizing Capitalism, Chicago: University of Chicago Press.

Hodgson, G. M. (2020), 'And Some Amiable Notes from Me Too'. Online: https://winir.org/content/documents/ WINIRDebateGreatEnrichment2020/Hodgson_Notes-WINIR-Debate_Great-Enrichment-2020-12-16.pdf.

Klamer, A. (2007), Speaking of Economics: How to Get Into the Conversation, London: Routledge.

Klamer, A. (2017), Doing the Right Thing: A Value Based Economy, Arjo Klamer. London: Ubiquity Press.

Koopmans, T. C. (1957), Three Essays on the State of Economic Science, New York: McGraw-Hill.

Langlois, R. N. (2016), 'Institutions for Getting Out of the Way', Journal of Institutional Economics, 12(1): 53-61.

Lawson, R. A. (2016), 'Can two Observations Confirm a Theory? A Comment on Max U Versus Humanomics', Journal of Institutional Economics, 12(1): 49-51.

McCloskey, D. N. (1985 (2nd ed. 1998)), The Rhetoric of Economics, Madison: University of Wisconsin Press.

McCloskey, D. N. (1990), If You're So Smart: The Narrative of Economic Expertise, Chicago: University of Chicago Press.

McCloskey, D. N. (1994), Knowledge and Persuasion in Economics, Cambridge: Cambridge University Press.

McCloskey, D. N. (2006), The Bourgeois Virtues: Ethics for an Age of Commerce, Chicago: University of Chicago Press.

McCloskey, D. N. (2010), Bourgeois Dignity: Why Economics Can't Explain the Modern World, Chicago: University of Chicago Press.

McCloskey, D. N. (2015), 'Max U Versus Humanomics: A Critique of Neo-Institutionalism', Journal of Institutional Economics, 12: 1-27.

McCloskey, D. N. (2016a), 'The Humanities are Scientific: A Reply to the Defenses of Economic Neo-institutionalism', Journal of Institutional Economics, 12(1): 63-78. doi: 10.1017/S1744137415000430.

McCloskey, D. N. (2016b), Bourgeois Equality: How Ideas, Not Capital or Institutions, Enriched the World, Chicago, Illinois: University of Chicago Press.

McCloskey, D. N. (2019), Why Liberalism Works: How True Liberal Values Produce a Freer, More Equal, Prosperous World for All, New Haven: Yale University Press.

McCloskey, D. N. (2020a), Historical Impromptus: Notes, Reviews, and Responses on the British Experience and the Great Enrichment, Great Barrington: American Institute for Economic Research.

McCloskey, D. N. (2020b), ‘Amiable Notes on Our Conversation'. Online: https://winir.org/content/documents/ WINIRDebateGreatEnrichment2020/McCloskey_Notes-WINIR-Debate_Great-Enrichment-2020-12-15.pdf.

McCloskey, D. N. (2021a), Bettering Humanomics: A New, and Old, Way of Doing Economic Science, Chicago: University of Chicago Press.

McCloskey, D. N. (2021b), Beyond Behaviorism, Positivism, and Neo-Institutionalism in Economics, Chicago: University of Chicago Press.

McCloskey, D. N. (2021c), 'Apologia Pro Vita Sua: A History of My Economic Opinions', Schmollers Jahrbuch: the Journal of Contextual Economics (forthcoming).

McCloskey, D. N. (2021d), 'The Statist Neo-Institutionalism of Acemoglu and Robinson', Research in the History of Economic Thought and Methodology and in Rivista di Storia Economica (forthcoming).

North, D. C. (2005), Understanding the Process of Economic Change. Princeton Economic History of the Western World, Princeton: Princeton University Press.

North, D. C., J. J. Wallis and B. R. Weingast (2009), Violence and Social Orders: A Conceptual Framework for Interpreting Recorded History.

Ostrom, E. (1990), Governing the Commons: The Evolution of Institutions for Collective Action, New York: Cambridge University Press.

Rorty, A. O. (1983), 'Experiments in Philosophical Genre: Descartes' Meditations', Critical Inquiry, 9(3): 545-565.

Smith, A. (1776), An Inquiry Into the Nature and Causes of the Wealth of Nations (Vol. 1), Glasgow ed. Edited by Campbell, Skinner, and Todd. Indianapolis: Liberty Classics, 1976. 1981.

Smith, V. and B. J. Wilson (2019), Humanomics, Cambridge: Cambridge University Press.

Storr, V. H. (2019), 'Ludwig Lachmann's Peculiar Status within Austrian Economics', Review of Austrian Economics, 32(1): 63-75.

Tabellini, G. (2016), 'Ideas or Institutions? - A comment', Journal of Institutional Economics, 12(1): 43-48.

Tallis, R. (2011), 'Rethinking Thinking. How a Lumpy Bunch of Tissue Lets us Plan, Perceive, Calculate, Reflect, Imagine and Exercise Free Will', Wall Street Journal, November 12.

Wallerstein, I. (1983 (1995)), Historical Capitalism with Capitalist Civilization, London: Verso.

Wilson, B. J. (2010), 'Social Preferences Aren’t Preferences', Journal of Economic Behavior \& Organization, 73(1): 77-82.

Cite this article: McCloskey DN, Silvestri P (2021). Beyond behaviorism, positivism, and neo-institutionalism in economics: a conversation with Deirdre Nansen McCloskey. Journal of Institutional Economics 17, 717-728. https://doi.org/10.1017/ S174413742100031X 